\title{
Languge Hybrid; Code Switching and Code Mixing by Students of Islamic Secondary School in Banyuwangi
}

\author{
Ulfa Gusnaini ${ }^{1}$, Rina Mahdiyana ${ }^{2}$, and Devinia Hepdian Syafitri ${ }^{3}$ \\ 1,2, 3 University of 17 Agustus 1945 Banyuwangi \\ 1 ulfagusnaini31@gmail.com \\ Abstract
}

Code-switching and Code-mixing are commonly treated as a phenomenon of the spoken language, and in linguistics referring to using more than one language in conversation. This research is done in Al-Kautsar Modern Female Islamic Boarding School (PPMP Al-Kautsar) Srono, Banyuwangi with the participant are all of Al-Kautsar students. This research using the observation method. The steps for analysis are first, the researchers collected notes and transcripts. Second, each data are labeled. Third, all codes identified so that the results are obtained. The entire code mix/switching founded are included as interstitial code mix/switching. There are several factors in using Codeswitching and Code-mixing. The first is because of the habit of adding certain phrases such as what is? as the replacement of certain words or phrases. The second is the lack phase of finding the right words from Ind onesian, Javanese, or Arabic into English considering the conversation is expected to keep running. From the observation, it is known that the phenomena of code mix/switching are occurred to smooth the communication function.

Keywords: Code-switching, code-mixing, language hybrid.

\section{INTRODUCTION}

At present English is a necessity in a modern era, which encourages everyone to learn and apply it in their daily lives. By applying English in everyday conversation, there will be much that can be obtained, among others because English is a global language, so we will be able to understand everything more easily. Modern impressions can also be obtained if we use English in everyday conversation. The use and application of English in education is certainly a major factor that must be implemented even some schools have begun to apply international language into everyday life. As one of the educational institutions in Banyuwangi, that is Al-Kautsar Modern Female Islamic Boarding School (PPMP AI-Kautsar) in Sumbersari, Srono, Banyuwangi.

In PPMP Al-Kautsar which has applied the international language, it is a communication tool, so students have the provision and are ready to face the needs in the era of globalization. PPMP AlKautsar is located on the main road of Pandan No.361 Sumbersari Srono Banyuwangi, East Java. This boarding school is sheltered by foundations managed by modern management based on Ahlussunnah Wal Jamaah. The education system in this pesantren implements a boarding school system or 24 hours dormitory. This is intended to guarantee quality education and facilitates caregivers and teachers to provide guidance and direction and supervision services. Consists of three formal education institutions namely

Junior High School (MTs) of Al-Kautsar, Senior High School (MA) of Al-Kautsar, and Madin of Al-Kautsar. PPMP AI-Kautsar curriculum uses several curricula including the curriculum implemented by the Indonesian Ministry of Religion for the formal education of MTs Al-Kautsar and the Department of Education curriculum and National for Al-Kautsar High School formal education.

In addition to the formal curriculum and Salafiyah pesantren curriculum, here is also a local content curriculum that is related to the enhancement of foreign bilingual skills, namely English and Arabic daily conversation. Foreign bilingual skills such as English and Arabic are applied in the daily conversation of the students so that this program can improve the ability of the students to use foreign bilingual. It is expected that with this English and Arabic daily conversation program students will be 
able to continue their education to a higher level both inside and outside the country with sufficient supplies.

In applying for the English daily conversation program there are a set of methods used to guarantee the continuity of this program, including adding new vocabulary per day and supervision of the language section (one part of the intra-female student's organization) so that the discipline of the students in carrying out the English daily conversation can be controlled continuously. One way to control them is by having a kind of punishment for students who violate this program. For example, when there is a student who uses a language other than English, the language section will take action.

However, it does not rule out the possibility of transfer or mixing of English with other languages or the first language of students. This is due to the varying levels of intellectual intelligence of the Santri who are there. Forget about the English vocabulary in question even though the conversation must keep going and don't know what the English vocabulary that matches what is meant is the reason that is generally experienced by female students so that they use this language or change language into their first language.

In this case, to avoid the punishment given by the language section they usually use certain phrases juxtaposed with the intended vocabulary. The most commonly used phrases are "what is?" And "what is the meaning of ...?" By using these phrases their language errors can be forgiven. Some examples of mixed code and code-switching carried out by the students are "I feel my stomach is very full, I eat ke much en", "you must drink medicine, or you can make herbal traditional. Make it from jeruk nipis mixing with kecap ". With the hope that their conversation errors can be forgiven by the language section, the pattern of the speech becomes "I feel my stomach is very full, I eat ke much en, what is?" And "you must drink medicine, or you can make herbal traditional. Make it from jeruk nipis mixing with kecap. What is the meaning of jeruk nipis and kecap?"

Code-switching and code-mixing carried out by Al-Kautsar students is a phenomenon that usually occurs in a place or environment where two or more languages are used as a means to communicate. What factors make the phenomenon of code-switching and code-mixing happen requires further research. This research will have a contribution to the field of linguistics, especially towards Sociolinguistics. With the absence of research that has been done regarding code-switching and code-mixing in this boarding school, this has become necessary. With the problem of what types of code-switching and code-mixing are spoken and what is the cause of the code-switching and codemixing produced by PPMP Al-Kautsar students, this research is held.

\section{LITERATURE REVIEW}

Code-switching is a means of shifting contextualization (Gumperz, 1982). The broad definition of code-switching is given by Gumperz (1982) as' juxtaposition in the same exchange of utterances from parts which include two different grammatical systems or subsystems.

Studies show that code-switching and patterns of use of two languages and different combinations are found because of the language structure and social and cultural background of the speakers. According to Poplack (1980), codeswitching is a change of two languages in one discourse or sentence or constituency. Thus, Poplack proposed two constraints that apply to code-switching: 'equality' and free morpheme. Although the Poplack model has long been in the literature, there are newer studies and have found the constraints of bilingual/trilingual code-switching, as in the case of Indo-Europeans and non-Indo-European languages in the same discourse.

Grosjean's (2001) proposes the Language Mode Hypothesis, in which the speaker moves from 
a monolingual situation where it is then deactivated and then goes to the next two languages or three languages. In this paper, code-switching is used as a comprehensive term for each transition between two or more languages. and if necessary, the difference is made using the intersentential term (ie a switch between two clauses or sentences) and intrasentential (ie a switch in the clause) codeswitching.

Very often, code-mixing is used synonymously with code-switching (Annamalai, 2001; Backus, 1992; Kachru, 1983) and means intersentential code-switching. This phenomenon is also welldocumented by Murshad (2002), and he found that the children did not just use a phrase from their first and another from their second language, and to make the languages work together, the children invented a third grammar that acted as hooks between the two languages.

\section{METHODOLOGY}

In PPMP Al-Kautsar Banyuwangi, there are 181 students, all of the objects of research that we examined are all Al-Kautsar students. We did this activity using the observation method, where we as researchers directly contributed to the day-to-day activities of the students. During the study, all materials consisted of ordinary conversations where the topics discussed were varied ranging from daily activities to discussions about specific people and events.

Data are included in notes and transcripts. Several steps are taken for data analysis. Firstly, the researcher collected records and transcripts to identify all things about code-mixing and codeswitching. Secondly, each data are encoded and labeled according to its function. Thirdly, all codes are filtered and identified so that the results of the research are obtained.

\section{RESULT AND DISCUSSION}

From the research that has been done, there are 16 items code-mixing and code-switching. The entire code-mixing and code-switching are included in the interstitial code-mixing and codeswitching because the displacement in this language is 1 clause or sentence. The following is the analysis:

1. Help me please take kan my pen

This is morpho-syntactical code-mixing. Morphological code-mixing is called because in this clause there is a transition from one code to another code, namely from English to Indonesian, namely the existence of "dong" and "kan". Syntactically the compilation of the recommended clause is "help me to take my pen". The factor that influences the occurrence of code-mixing is the habit of adding morpheme "dong" and "kan" in everyday conversation.

\section{So how nganunya diperbaiki}

This is morpho-syntactical code-switching. It is called morphological codeswitching because in this clause there is a transition from one code to another, namely from English to Javanese and Indonesian, that is, there is a "fix it". Syntactically the preparation of the recommended clause is "so how to repair it". The factors that influence this code-switching are the lack of phase in finding the right word from Javanese into English and also the lack of phase in the preparation of correct English sentence patterns.

3. I think I do not delicious body

This is syntactical code-switching. Syntactical code-switching is called because in this clause there is an inaccuracy in the placement of the word "delicious body" and the inaccuracy of the sentence pattern. Syntactically the compilation of the recommended clause is "I think I dont feel 
very well". The factors that influence the occurrence of this code-switching is the lack of phase in finding the right word for "feeling unwell" and also the lack of phase in the preparation of correct English sentence patterns.

4. I ... uh all of broken kan?

This is morpho-syntactical code-mixing. Morphological code-mixing is called because in this clause there is a transition from one code to another, namely from English to Indonesian, which is "kan". Syntactically the compilation of the recommended clause is "all thing' has broken, kan?". The factors that influence this code-mixing are the habit of adding "kan" in everyday conversation and also the lack of phase in the preparation of correct English sentence patterns.

5. You coming coming angry again

This is syntactical code-switching. It is called syntactical code-switching because in this clause there is an inaccuracy in placing the "coming-coming" phrase that follows the Indonesian pronunciation pattern. Syntactically the compilation of the recommended clause is "you are coming here, not angry again". The factors that influence the occurrence of this code-switching is the lack of phase in the preparation of correct English sentence patterns.

6. You know I lah

This is morpho-syntactical code-mixing". It is called morphological code-mixing because in this clause there is a transition from one code to another code, from English to Indonesian, that is "lah". Syntactically the compilation of the recommended clause is "you know me well". The factors that influence this code-mixing are the habit of adding "lah" in everyday conversation and also the lack of phase in the preparation of correct English sentence patterns.

7. Your face likes that Iho

This is morphological code-mixing. Morphological code-mixing is called because in this clause there is a transition from one code to another code, from English to Indonesian, that is "you know". Syntactically the preparation of the recommended clause is "your face is like that Iho". The factors that influence code-mixing are the habit of adding "you know" in everyday conversation.

8. No! You will go there ambi she

This is morpho-syntactical code-mixing or code-switching. Morphological code-mixing is called because in this clause there is a transition from one code to another, namely from English to Indonesian, which is "ambi". Called morphological code-switching because in this clause there is a transition from one code to another code, from English to Javanese, that is "ambi". Syntactically the preparation of the recommended clause is "No! You went with her ". The factors that influence this code-mix or code-switching are the habit of adding "ambi" in everyday conversation and also the lack of phase in the placement of the right words from Javanese to English and also the lack of phase in the preparation of correct English sentence patterns.

9. I feel my perut anu ... sick

This is morpho-syntactical code-switching. Morphological code-switching is called because in this clause there is a transition from one code to another code, namely from English to Indonesian, namely the existence of "perut", and the transition from English to Javanese is "anu". Syntactically the compilation of the recommended clause is "I got stomach-ache". Factors that influence codeswitching are the habit of adding "anu" in everyday conversation and also lacking internal phases.placement of words from Indonesian into English and lack of phase in the preparation of correct English sentence patterns. 
10. Hey! Why is your book no arti? How to say arti

This is morpho-syntactical code-switching. This is called morphological code-switching because in this clause there is a transition from one code to another code, from English to Indonesian, that is the "arti". Syntactically the preparation of the recommended clause is "hey! Why does your book without arti?" The factors that influence this code-switching are the lack of phase in the placement of word matching from Indonesian to English and the lack of phase in the preparation of correct English sentence patterns.

11. You remember me putting the book of lugowi where

This is morpho-syntactical code-switching. Morphological code-switching is called because in this clause there is a transition from one code to another code, from English to Indonesian, that is "taruh", and the transition from English to Arabic "Kitab Lugowi". Syntactically the compilation of the recommended clause is "do you remember where I taruh my lugowi book?". The factors that influence this code-switching are the lack of phase in the placement of word matching from Indonesian to English and the lack of phase in the preparation of correct English sentence patterns.

12. Sister !! you dicari nindy! in room now

This is morpho-syntactical code-switching. Morphological code -witching is called because in this clause there is a transition from one code to another code, from English to Indonesian, that is, "dicari". Syntactically the preparation of the recommended clause is "sister! You are looked at by Nindy in the room now ". The factors that influence this code-switching are the lack of phase in the placement of word matching from Indonesian to English and the lack of phase in the preparation of correct English sentence patterns.

13. Hi, vinda kalau speak like that like that Iho

This is morpho-syntactical code-mixing or code-switching. Morphological code-switching is called because in this clause there is a transition from one code to another code, from English to Indonesian, that is "kalau". And the mixing code is the addition of "Iho". Syntactically the compilation of the recommended clause is "hi, vinda you are always speak like that". The factor that influences the code-mix/code-switching is the lack of phase in the placement of words from Indonesian to English and the habit of adding: "you know" in everyday conversation.

\section{Your sya'run out! enter to cloth now}

This is morpho-syntactical code-switching. Morphological code-switching is called because in this clause there is a transition from one code to another code, from English to Arabic, namely "sya'run" which means hair. Syntactically the preparation of the recommended clause is "your hair is out of your veil, please cover it". The factors that influence this code-switching are the lack of phase in the placement of words from Arabic to English and the lack of phase in the preparation of correct English sentence patterns.

15. Monica, your dress not lipet? Because your cloth is dry

This is morpho-syntactical code-switching. Morphological code-switching is called because in this clause there is a transition from one code to another code, namely from English to Indonesian, namely "lipet/lipat". Syntactically composing the recommended clause is "Monica, don't you foald your dress? Your cloth was dry already". The factors that influence this code-switching are the lack of phase in the placement of word matching from Indonesian to English and the lack of phase in the preparation of correct English sentence patterns. 
16. You speak what ha? ..

This is morpho-syntactical codemixing. It is called morphological code-mixing because in this clause there is a transition from one code to another code, from English to Indonesian, that is "ha!". Syntactically the compilation of the recommended clause is "what do you speak?". The factors that influence this code-mixing are the habit of saying such sentence patterns and the habit of adding "ha" in everyday conversation.

From the analysis above there is $81.25 \%$ use of morpho-syntactical code mix/switching. While the use of syntactical code-switching is $12.5 \%$ of the total data. Then the last is the use of morphological code-mixing is $6.25 \%$ of the overall data. Several factors cause the code-mixing/codeswitching to occur because of the habit of using certain phrases such as right, it is, you know, in everyday conversations are also habits in using certain sentence patterns. As in "you speak what?". This Clause, the use of sentence patterns because of habits, not because of ignorance in the preparation of correct English sentence patterns.

The second contributing factor is the lack of phase in finding the right words from Indonesian, Javanese, Arabic into English. From the observation, it is known that the code mix/switching that occurs is to smooth the communication function. Although there is a habit of code-switching and lack of phase in the preparation of correct English sentence patterns, it is all neglected considering the communication function that is expected to keep running.

\section{CONCLUSION}

It can be concluded that from the research that the phenomena of code-mixing/codeswitching can be found in PPMP Al-Kautsar. The entire code-mixing/code-switching founded are included as interstitial code-mixing/code-switching because the displacement in the language is one clause/sentence. From the analysis we have done, there is $81.25 \%$ of the use of morpho-syntactical code-mix/code-switching. While the use of syntactical code-switching is $12.5 \%$ of the total data. Then the last is the use of morphological code-mixing is $6.25 \%$ of the overall data.

There are several factors why the use of occurs. The first is that because of the habit of adding certain phrases such as right? what is? you know? in everyday conversations are also habits in using certain sentence patterns. As in "you speak what?" as the replacement of the certain word or phrases whenever they are fell difficult in finding the correct word or phrases in the target language. The second contributing factor is the lack phase of finding the right words from Indonesian, Javanese, Arabic into English while considering that the conversation is expected to keep running. From the observation, it is known that the phenomena of code-mixing/code-switching are occurred to smooth the communication function. Although there is a habit of code-mixing/code-switching and lack of phase in the preparation of correct English sentence patterns, they are all neglected considering the communication function that is expected to keep running.

\section{REFERENCIES}

Annamalai, E. (2001). Managing multilingualism in India: Political and linguistic manifestations. Thousand Oaks, CA: Sage.

Backus, A. (1992). Patterns of language mixing: A study in Turkish-Dutch bilingualism. Wiesbaden: O. Harrassowitz.

Grosjean, F. (2001). The bilingual's language modes. 
Ulfa Gusnaini ${ }^{1}$, Rina Mahdiyana ${ }^{2}$, and Devinia Hepdian Syafitri ${ }^{3}$

In J. L. Nicol (Ed.), One mind, two languages: Bilingual language processing (pp.1-22). Malden, MA: Blackwell.

Gumperz, J. J. (1982). Discourse strategies Cambridge: Cambridge University Press.

Hasan, M. K., \& Akhand, M. M. (2014). Reviewing the challenges and opportunities presented by code-switching and mixing in Bangla. Journal of Pan-Pacific Association of Applied Linguistics, 18(2), 63-75.

Kachru, B. B. (1983). The Indianization of English: The English language in India. Oxford: Oxford University Press

Murshad, A. H. (2002). Tools for talking: The purposeful and inventive use of languages by bilingual children in primary classrooms. Reading Literacy and Language, 36(3), 106-111.

Poplack, S. (1980). Sometimes I'll start a sentence in English y termino en Espanol: Toward a typology of code-switching. Linguistics, 18,581-618. 